\title{
Testosterone and corticosterone concentrations in the plasma of rats deficient in vitamin $\mathrm{E}$
}

\author{
D. Lees, M. McC. Barnes and J. E. Cox* \\ Department of Biochemistry, University of Liverpool, Liverpool L69 3BX, and *Department of \\ Veterinary Clinical Studies, University of Liverpool Veterinary Field Station, Leahurst, Neston, \\ Wirral L64 7TE, U.K.
}

Summary. Plasma testosterone and corticosterone concentrations in male rats given a diet deficient in vitamin $E$ for 130 days were significantly lower than those in rats given the same diet supplemented with vitamin $\mathrm{E}$.

\section{Introduction}

The histopathological changes that occur as testicular degeneration progresses in the vitamin E-deficient rat are well documented (for review see Mason, 1926, 1933), but very little attention has been paid to the hormone status of the animal. Barnes, Smith \& Leonard (1974) have shown that urinary 17-oxosteroid excretion is reduced in vitamin $\mathrm{E}$ deficiency and Barnes, Smith \& Lees (1978) reported decreased activity of some of the enzymes involved in steroid hormone synthesis in adrenal and testicular tissue. In the present investigation we measured the concentrations of corticosterone and testosterone in the plasma of rats deficient in vitamin $\mathrm{E}$ and of control rats given vitamin $\mathrm{E}$.

\section{Materials and Methods}

Weanling male albino rats that had been bred in this laboratory were given a diet low in vitamin $\mathrm{E}$, based on dried skimmed milk (to provide $20 \%$ protein), $7 \%$ lard and sucrose, supplemented with vitamins $\mathrm{B}, \mathrm{D}$ and $\mathrm{K}$ and minerals. Vitamin A (retinyl acetate, 5000 i.u./100 g diet) was added twice weekly. Rats given this diet have been shown to exhibit the classical signs of vitamin E deficiency, i.e. testicular degeneration in the male and fetal resorption which was reversible by vitamin $E$ supplementation in the female. Vitamin $E$ ( $\alpha$-tocopheryl acetate) was added twice weekly to the diet given to the control group to provide $1 \mathrm{mg} / \mathrm{rat} / \mathrm{day}$.

Plasma $\alpha$-tocopherol was measured by a fluorometric method based on that of Duggan (1959). Plasma $(0.5 \mathrm{ml})$ was added to a tube containing $0.5 \mathrm{ml}$ ethanol (spectroscopically pure) and the contents were mixed for $45 \mathrm{sec}$ on a Whirlimixer. The tubes were centrifuged for $\sim 3 \mathrm{~min}$ at $500 \mathrm{~g}$ and the upper solvent layer was transferred to another tube. Then $0.5 \mathrm{ml}$ cyclohexane was added to the plasma layer and the contents of the tube were mixed and centrifuged again. The second cyclohexane extract was added to the first and the combined extracts made up to 3 $\mathrm{ml}$ volume with cyclohexane. No further increase in tocopherol was found after a third extraction. The fluorescence due to $\alpha$-tocopherol was measured in a fluorescence spectrophotometer (Hitachi MPF 2A). The optimum emission was produced by excitation at $297 \mathrm{~nm}$ 
and measurement of the emission was at $324 \mathrm{~nm}$. Standard curves for samples containing 0.25-6 $\mu \mathrm{g} \alpha$-tocopherol were linear and reproducible from day to day. Higher levels of $\alpha$-tocopherol required different sensitivity settings, but again a linear relationship was found and the results were reproducible. Standard solutions of $\alpha$-tocopherol were always assayed alongside the serum samples.

Corticosterone was measured fluorometrically by the method of Kitabchi \& Kitchell (1970).

Testosterone levels in the plasma samples were measured by radioimmunoassay using an antibody raised in sheep to testosterone-3-oxime-BSA which was highly specific for testosterone, having a significant cross-reaction only with $5 \alpha$-dihydrotestosterone $(7.5 \%)(C o x$, Williams, Rowe \& Smith, 1973). All samples were analysed in one assay. The coefficient of variation between the duplicates was $8.7 \%$. The antibody bound $65 \%$ of the counts added at the zero point on the standard curve and $33 \%$ at the $100 \mathrm{pg}$ testosterone point. When $100 \mathrm{pg}$ unlabelled testosterone were added to $0.1 \mathrm{ml}$ serum from castrated rats, the average recovery of testosterone was $104.7 \%(n=7)$. Results were expressed in $\mathrm{pg} / \mathrm{ml}$ without correction for losses involved in extraction (known to be only about $5 \%$ ).

\section{Results}

The rats given the diet deficient in vitamin $E$ for 130 days from weaning were significantly smaller and had smaller testes, seminal vesicles and prostate glands than did the control group (Table 1). The extent of the vitamin E deficiency was demonstrated by the difference in plasma tocopherol levels. Calculation of the results in relation to body weight showed that there was still a significant difference between testicular weights of the 2 groups $(P<0.05)$ but that for seminal vesicle and prostate gland weights was removed $(P=0.07)$. The vitamin E-deficient rats had significantly $(P<0.05)$ lower mean \pm s.e.m. concentrations of plasma testosterone $(917 \pm 125$ $\mathrm{pg} / \mathrm{ml}, \mathrm{N}=12)$ and corticosterone $(82.5 \pm 7.2 \mathrm{ng} / \mathrm{ml}, \mathrm{N}=11)$ than did the rats given vitamin $\mathrm{E}$ supplement ( $1463 \pm 145 \mathrm{pg}$ testosterone $/ \mathrm{ml}, \mathrm{N}=13$, and $107.4 \pm 6.5 \mathrm{ng}$ corticosterone $/ \mathrm{ml}, \mathrm{N}$ $=12$ ). There was no significant correlation between testosterone concentration of individual rats and seminal vesicle weight, although the mean seminal vesicle weight was significantly lower in the vitamin E-deficient rats.

Table 1. Body, gonadal and accessory sex gland weights and $\alpha$-tocopherol values in male rats given a diet deficient in vitamin $\mathrm{E}$ for 130 days (-E), and control rats given the same diet supplemented with vitamin $\mathrm{E}(+\mathrm{E})$

\begin{tabular}{lcc}
\hline & $+\mathrm{E}$ & $-\mathrm{E}$ \\
\hline Body weight $(\mathrm{g})$ & $410 \pm 12$ & $356 \pm 10^{*}$ \\
Testes weight $(\mathrm{g})$ & $3 \cdot 10 \pm 0.03$ & $2.32 \pm 0.06^{*}$ \\
Seminal vesicle weight $(\mathrm{mg})$ & $1109 \pm 60$ & $816 \pm 58^{*}$ \\
Prostate gland weight $(\mathrm{mg})$ & $273 \pm 15$ & $202 \pm 8^{*}$ \\
$\alpha$-Tocopherol $(\mu \mathrm{g} / \mathrm{ml})$ & $6.82 \pm 0.13$ & $0.57 \pm 0.06^{*}$ \\
\hline
\end{tabular}

Values are mean \pm s.e.m. for 18 rats/group. $(t$ test).

* Significantly different from values for $+\mathrm{E}$ rats, $P<0.001$

\section{Discussion}

Removal of the pituitary from male rats produces a number of effects similar to those seen in vitamin E deficiency, e.g. a reduction in some steroid enzyme activities (Samuels \& Helmreich, 
1956; Shikita \& Hall, 1967), in in-vitro androgen synthesis (Steinberger \& Ficher, 1973) and concentrations of androgens in testis and in plasma (Hall, 1970; de Jong, Hey \& van der Molen 1973). These changes in vitamin E-deficient rats could be brought about by reduced pituitary hormone production, reduced response of the target tissue to the trophic hormone, or by some more fundamental biochemical change in the cells resulting in reduced production of steroid hormones.

We thank Professor C. A. Finn for castrating the rats used in the testosterone assay; and the M.R.C. for a research studentship (D.L). The technical assistance of Miss M. Forrest and the financial support of The Horserace Betting Levy Board with the testosterone measurements is gratefully acknowledged.

\section{References}

Barnes, M.McC., Smith, A.J. \& Leonard, P.J. (1974) The excretion of 17 -oxosteroids by rats deficient in vitamin E. Int. J. Vit. Nutr. Res. 44, 46-52.

Barnes, M.McC., Smith, A.J. \& Lees, D. (1978) Vitamin $\mathrm{E}$ and steroidogenesis. In Tocopherol Oxygen and Biomembranes, pp. 221-231. Eds C. de Duve \& O. Hayaishi. Elsevier/North Holland, Amsterdam.

Cox, J.E., Williams, J.H., Rowe, P.H. \& Smith, J.A. (1973) Testosterone in normal, cryptorchid and castrated horses. Equine vet. J. 5, 85-90.

de Jong, F.J., Hey, A.H. \& van der Molen, H.J. (1973) Effect of gonadotrophin on the secretion of oestradiol-17\% and testosterone by the rat testis. $J$. Endocr. 57, 277-284.

Duggan, D.E. (1959) Spectrofiuorometric determination of tocopherols. Arch. Biochem. Biophys. 84, 116122.

Hall, P.F. (1970) Endocrinology of the testis. In The Testis, Vol. II, pp. 2-71. Eds A. D. Johnson, W. R. Gomes \& N. L. VanDemark. Academic Press, New York.

Kitabchi, A.E. \& Kitcheil, C.L. (1970) A simplified fluorometric method for the determination of blood corticosterone using phase separating filter paper: Analyt. Biochem. 34, 529-534.

Mason, K.E. (1926) Testicular degeneration in albino rats fed a purified food ration. J. exp. Zool. 45, 159-229.

Mason, K.E. (1933) Differences in testis injury and repair after vitamin A deficiency, vitamin $\mathrm{E}$ deficiency and inanition. Am.J. Anat. 52, 153-239.

Samuels, L.T. \& Helmreich, M.L. (1956) The influence of chorionic gonadotrophin on the $3 \beta-o l$ dehydrogenase activity of testes and adrenals. Endocrinology $58,435-442$.

Shitita, M. \& Hall, P.F. (1967) Action of human chorionic gonadotrophin in vivo upon microsomal enzymes in testes of hypophysectomized rats. Biochim. Biophys. Acta 141, 433-435.

Steinberger, E. \& Ficher, M. (1973) Effect of hypophysectomy and gonadotrophin treatment on metabolism of ${ }^{3} \mathrm{H}$-progesterone by rat testicular tissue. Steroids 22, 425 . 